Nat. Hazards Earth Syst. Sci., 19, 93-105, 2019

https://doi.org/10.5194/nhess-19-93-2019

(C) Author(s) 2019. This work is distributed under

the Creative Commons Attribution 4.0 License.

\title{
Characteristics and influencing factors of rainfall-induced landslide and debris flow hazards in Shaanxi Province, China
}

\author{
Ke Zhang ${ }^{1}$, Sheng Wang ${ }^{1}$, Hongjun $\mathrm{Bao}^{2}$, and Xiaomeng Zhao ${ }^{3}$ \\ ${ }^{1}$ State Key Laboratory of Hydrology-Water Resources and Hydraulic Engineering, and College of Hydrology and Water \\ Resources, Hohai University, Nanjing, Jiangsu, 210098, China \\ ${ }^{2}$ National Meteorological Center, China Meteorological Administration, Beijing, 100081, China \\ ${ }^{3}$ Shaanxi Climate Center, Xi' an, Shaanxi, 710014, China
}

Correspondence: Ke Zhang (kzhang@hhu.edu.cn) and Hongjun Bao (baohongjun@cma.gov.cn)

Received: 9 September 2018 - Discussion started: 12 September 2018

Accepted: 19 December 2018 - Published: 14 January 2019

\begin{abstract}
Shaanxi Province, located in northwest China and spanning multiple hydroclimatic and geological zones, has many areas largely suffering from rainfall-induced landslide and debris flow. The objectives of this study are to reveal the spatiotemporal characteristics of the two hazards and identify their major controlling factors in this region based on a region-wide, comprehensive ground-survey-based hazard inventory dataset from 2009 to 2012 . We investigated the spatiotemporal characteristics of the two hazards and quantified the relationships between the occurrence rates of the two hazards and their influencing factors, including antecedent rainfall amount, rainfall duration, rainfall intensity, terrain slope, land cover type and soil type. The results show that landslide has a higher occurrence rate and more extensive distribution than debris flow in this region, while the two hazards are both concentrated in the south with ample rainfall and steep terrains. Both of the hazards show clear seasonalities: July-September for landslide and July for debris flow. Rainfall characteristics (amount, duration and intensity) and slope are the dominant factors controlling slope stability across this region. Debris flow is more sensitive to these rainfall metrics on the high-value ranges than landslide in this region. Land cover is another influencing factor but soil type does not appear to impose consistent impacts on the occurrence of the two hazards. This study not only provides important inventory data for studying the landslide and debris flow hazards but also adds valuable information for modeling and predicting the two hazards to enhance resilience to these hazards in this region.
\end{abstract}

\section{Introduction}

Landslides and debris flows are two widespread and destructive natural hazards around the world (Peruccacci et al., 2012; Huang et al., 2017; Nicolussi et al., 2015; Blothe et al., 2015; Wooten et al., 2008; Hong et al., 2007), which can cause large casualties and economic losses (Jaboyedoff et al., 2012; Hong et al., 2017b; Zhang et al., 2016). Globally, landslides are responsible for approximately 1000 deaths and about USD 4 billion in property losses per year (Pradhan and Youssef, 2010). Landslide-caused fatalities accounted for $17 \%$ of fatalities due to natural hazards $(\mathrm{H}$. Y. Hong et al., 2015). For debris flows, it is more difficult to quantify the resultant casualties and damages because it is hard to distinguish debris-flow-induced losses from the losses caused by concurrent flood or other hazards (Borga et al., 2014). China is severely affected by geological disasters, including landslide and debris flow (Petley, 2010; H. Y. Hong et al., 2015). Statistical reports by the Chinese Institution of Geological Environmental Monitoring showed that unexpected geological hazards lead to 1167 casualties and CNY 6.4 billion in property losses per year (Zhang et al., 2017). Other research reported that landslide disasters have caused about $1100 \mathrm{fa}$ talities and USD 5-10 billion in China since 2000 (Hong et al., 2017a).

Due to the massive casualties and property damages that landslide and debris flow may cause, it is essential to have a profound comprehension of the causes, e.g., heavy rainfall, earthquakes and human activities, of these disasters (Chen et al., 2015b). Landslide occurrence is a complex nonlinear process (Qin et al., 2001; Sorbino et al., 2010) that is influ- 
enced by many different factors such as geological features and hydrological conditions (Zhu et al., 2017). In many regions, rainfall is the primary trigger (Milne et al., 2012) of shallow landslides and debris flows that have posed significant threats to human lives and properties (Gariano et al., 2015; Pradhan and Youssef, 2010). Hence, numerous studies have been conducted on understanding and modeling the rainfall-induced landslides and debris flows.

The methods used to predict landslide occurrence can be divided into two general categories, statistical methods and physically based models. The representative statistical method is the rainfall threshold method (Guzzetti et al., 2007; Peruccacci et al., 2012; Gariano et al., 2015; Bogaard and Greco, 2018), which usually builds a simple statistical model quantifying the relationship of landslide occurrence rate or probability with cumulated rainfall (the total rainfall measured from the beginning of the rainfall event to the time of slope failure), rainfall intensity (the average rainfall intensity during the rainfall event) and/or rainfall duration. Physically based models usually use rainfall time series as input data to model the slope stability based on the physical processes and mechanisms. There are many physically based landslide forecasting models such as TRIGRS (Baum et al., 2010; Alvioli and Baum, 2016), SHALSTAB (Montgomery and Dietrich, 1994), SLIDE (Y. Hong et al., 2015; Liao et al., 2012) and SLIP (Montrasio and Valentino, 2008). Recently, several studies were conducted to couple the landslide models with distributed hydrological models to develop coupled flood-landslide models (He et al., 2016; Zhang et al., 2016). Modeling the movement and run-out extent of debris flow is a more complicated process than modeling the slope failure or the landslide occurrence. Numerical simulation of the debris flow process is usually based on shallow water equations (Han et al., 2017) and numerical solutions of mass and momentum conservation equations using finite-element and finite differential methods (Naef et al., 2006; Zhang et al., 2015).

Despite that various advanced methods and models have been used for the prediction of landslide and debris flow, it is still difficult to completely explain the physical mechanisms controlling slope failure and to accurately predict the occurrence of landslide and debris flow in most areas (Hong et al., 2017a; Althuwaynee et al., 2014). In addition, there have been limited efforts on landslide and debris flow prediction in Shaanxi Province, China, so far. Additionally, most previous studies were mainly focused in understanding and modeling landslides and/or debris flows in small and medium-sized areas (Chen et al., 2016, 2017; Sun et al., 2016; Zhuang and Peng, 2014). There is still limited knowledge on the characteristics, distributions, and influencing factors of landslide and debris flow hazards across this region.

Therefore, the objectives of this study are to reveal the spatiotemporal characteristics of rainfall-triggered landslide and debris flow hazards in Shaanxi Province and to identify the major controlling factors of the occurrence of the two haz- ards. To this end, we firstly compiled an inventory data of rainfall-induced landslide and debris flow events in Shaanxi Province for the period 2009-2012 provided by the geological survey office of the Department of Land and Resources of Shaanxi Province. Considering the interannual and intraannual differences in rainfall, we then analyzed the characteristics of spatiotemporal distributions of landslide and debris flow using statistical methods. Next, we derived the characteristics of rainfall processes, terrain slope, land cover type and soil type for each grid cell. Finally, we studied the relationships of landslide and debris flow occurrence rates with rainfall level, terrain slope, land cover type and soil type.

\section{Study area and data}

\subsection{Description of study area}

Shaanxi Province, situated in the middle of northwest China, is located between $105^{\circ} 29^{\prime}$ and $111^{\circ} 15^{\prime} \mathrm{E}$ longitude and between $31^{\circ} 42^{\prime}$ and $39^{\circ} 35^{\prime} \mathrm{N}$ latitude with a total area of about $205800 \mathrm{~km}^{2}$. Statistical data show that more than 38 million people live in Shaanxi. Altitude mostly ranges from 350 to $3500 \mathrm{~m}$ with a regional average slope of $19.9^{\circ}$ (Fig. 1a). In Shaanxi, elevation is higher in the north and south and lower in the middle (Fig. 1a). The average elevation of the Qinling Mountains is more than $2000 \mathrm{~m}$ and they stretch from east to west, representing an important natural line of demarcation between north and south China (Wu and Qian, 2017). The high elevations and relatively steep terrains in many areas of this region make them susceptible to both landslide and debris flow. The Bei Mountains and the Qinling Mountains divide Shaanxi Province into three geographical regions: Shaanbei Loess Plateau in the north, Guanzhong Plain (also known as Wei River basin) in the central area and Qinling-Dabashan Mountains in the south (Jiang et al., 2015). Because of this, land cover shows a distinct regional distribution from north to south: grasslands, cultivated lands and forests (Fig. 1b). The soil type in the study area is mainly loam (Fig. 1c).

The hydrological conditions of Shaanxi Province are diverse due to the diversity of its physiographic features and climate, which vary regionally and seasonally. The study area consists of three main climatic zones, the semiarid zone, semi-humid zone and humid zone, distributed from north to south. Regional mean annual temperature is about $6.5-16.6^{\circ} \mathrm{C}$. However, temperature decreases from south to north. Spatial average annual rainfall is $400-600,500-$ 700 and $700-900 \mathrm{~mm}$ in the northern, central and southern areas, respectively, while precipitation decreases from south to north and is significantly influenced by the mountains. In addition, rainfall has a strong seasonality in this region. Rainfall in summer is the greatest and accounts for $40 \%-$ $60 \%$ of annual rainfall. Rainfall of the remaining seasons decreases in the order of autumn, spring and winter. As rain- 

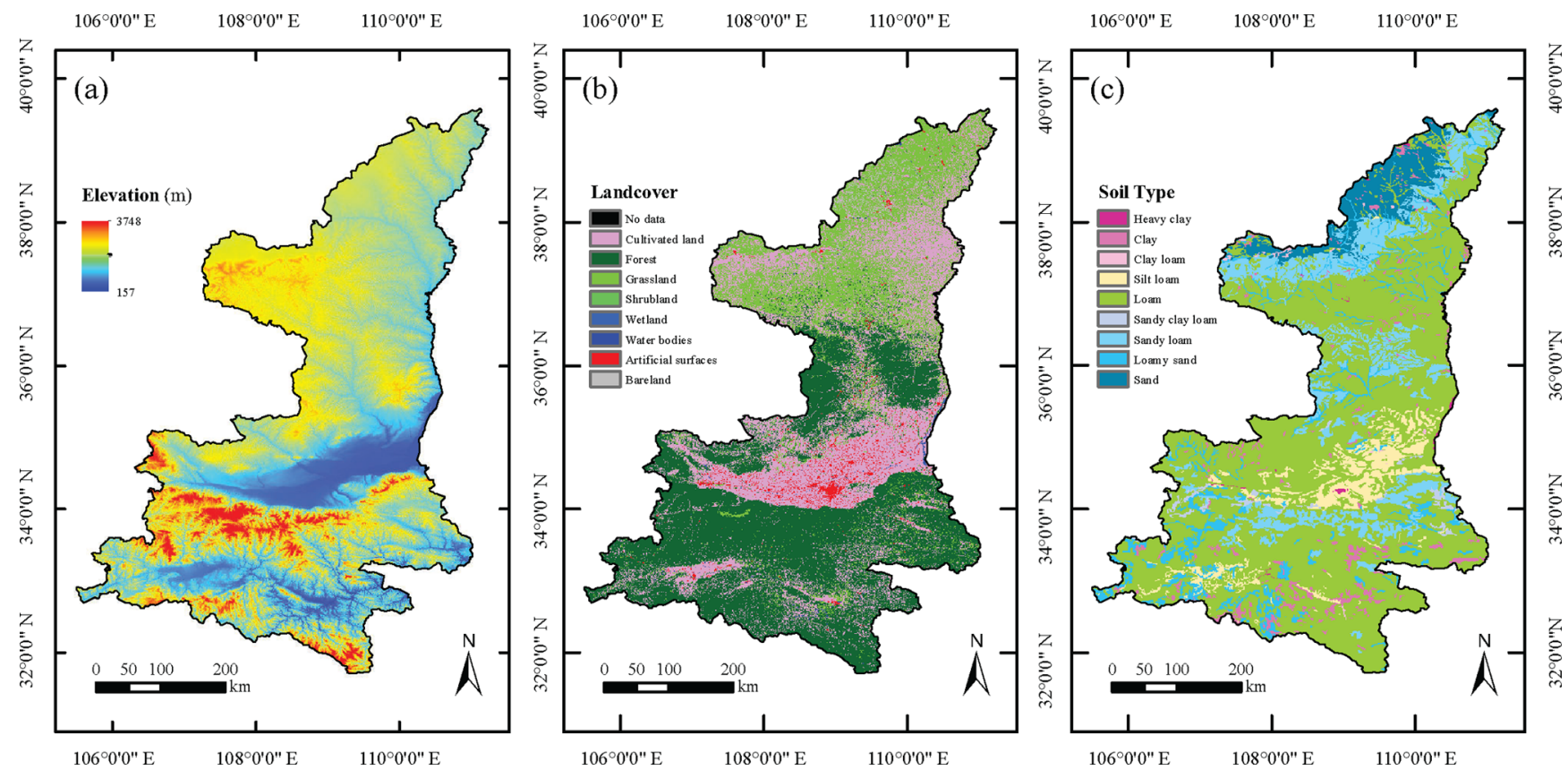

Figure 1. Spatial maps of (a) elevation, (b) land cover and (c) soil type across the study region.

fall is mostly concentrated in the monsoon season (MayOctober), rainfall-triggered landslide and debris flow occur frequently during this season.

\subsection{Datasets}

Data used in this study include rainfall, inventory data of geological hazards, digital elevation model (DEM), land cover and soil type. The rainfall, DEM, land cover and soil type data are gridded data, while the inventory data of landslide and debris flow hazards are a list of events with recorded locations (latitudes and longitudes), hazard types, causes, occurrence times and associated casualties.

The rainfall data are hourly observations from 756 stations provided by the China Meteorological Administration (CMA). We interpolated the site data into gridded data by using the inverse distance weighting method. The spatial resolution of the grid is $90 \mathrm{~m}$. The geological disaster data are from the geological survey office of Department of Land and Resources of Shaanxi Province. The DEM data with a spatial resolution of $90 \mathrm{~m} \times 90 \mathrm{~m}$ were downloaded from the geospatial data cloud (http://www.gscloud.cn; DEM data, 2017). This database covers land area from $60^{\circ} \mathrm{N}$ to $60^{\circ} \mathrm{S}$ and was released to the public in 2003.

The GlobeLand30-2010 product is a product of global land cover at a spatial resolution of $30 \mathrm{~m}$ derived from remotesensing images in 2010 (Chen et al., 2015a). The dataset covers land area from $80^{\circ} \mathrm{N}$ to $80^{\circ} \mathrm{S}$ and consists of 10 land cover types. These $30 \mathrm{~m}$ data were aggregated to $90 \mathrm{~m}$ resolution to match with the DEM data.
The soil data are from the Harmonized World Soil Database (HWSD) v1.2 (https://daac.ornl.gov/SOILS/ guides/HWSD.html; Soil data, 2017), which was compiled from four source databases, the European Soil Database (ESDB), the 1:1000000 soil map of China, various regional SOTER databases (SOTWIS database) and the FAO and FAO-UNESCO soil maps of the World. The soil database used in the research is classified based on the USDA classification method of soil texture, which includes 13 types. The soil data were also reprojected and resampled to the $90 \mathrm{~m}$ resolution.

\section{Methodology}

To reveal the spatiotemporal distributions of the rainfalltriggered landslide and debris flow hazards, we analyzed the spatial, latitudinal, interannual and seasonal distributions of these hazard events and the relationship of the number of hazard events with the corresponding rainfall amount.

To investigate the impacts of rainfall characteristics, including antecedent rainfall amount $\left(P_{\mathrm{a}}\right)$, rainfall duration $(D)$ and rainfall intensity $(I)$, terrain slope $(\theta)$, land cover type $(L)$, and soil type $(S)$ on the occurrence rates $(R)$ of the landslide and debris flow, we first projected the locations of these recorded hazard events onto the DEM grid with a spatial resolution of $90 \mathrm{~m}$. If multiple events of the same type of hazard occurred on the same grid cell within $1 \mathrm{~h}$, these events were treated as one event; the earliest occurrence time of these events is treated as the occurrence time of the combined event. From the $90 \mathrm{~m}$ DEM, we further computed the 
slope angles for each grid cell. We then tabulated all of the above gridded data with the following attributes: grid cell ID, rainfall event ID, rainfall amount, rainfall duration, rainfall intensity, rain intensity class, slope, land cover type, soil type and hazard type. We defined a rainfall event as an event with continuous rainfall or a combination of several discontinued rains with the non-rain intermittent periods less than or equal to $2 \mathrm{~h}$.

When we calculated the occurrence rate of one type of hazard, we excluded all grid cells without any reported event of this type of hazard and all rainless events from the analysis. The occurrence rate of a $k$ th type of hazard conditional on a given explanatory variable or its class $J\left(R_{j, k}\right)$ is defined as

$R_{j, k}=\frac{n(J==j \text { and } K==k)}{n[J==j \text { and }(K==k \text { or } K==0)]}$,

where $K$ is the hazard type (0,1 and 2 for rainfall event without causing any geological hazard, rainfall-induced landslide and rainfall-induced debris flow, respectively); $J$ is the class of $P_{\mathrm{a}}, D, I, \theta$, land cover type and soil type; $n(J==j$ and $K==k$ ) is the number of events of a given hazard $k$ when the corresponding $J$ belongs to the $j$ th class; and $n[J==i$ and $(K==k$ or $K==0)]$ is the number of positive and negative events of a given hazard $k$ when the corresponding $J$ belongs to the $j$ th class. In this study, we classified the rainfall amount, rainfall duration, rainfall intensity and rain type into five $(0-10,10-30,30-60,60-100$ and $>100 \mathrm{~mm})$, five $(0-3,3-12,12-24,24-36$ and $>36 \mathrm{~h})$, five $(0-1,1-2,2-$ $3,3-5$ and $>5 \mathrm{~mm} \mathrm{~h}^{-1}$ ) and four classes (light rain, moderate rain, heavy rain and violent rain), respectively. Following the American Meteorology Society (Glickman and Walter, 2000), light rain, moderate rain, heavy rain and violent rain are defined as rains when the precipitation rate is $<2.5,2.5-$ 7.6, 7.6-50 and $>50 \mathrm{~mm} \mathrm{~h}^{-1}$, respectively. We categorized the slope, land cover type and soil type into five $(0-2,2-5$, 5-10, 10-20 and $>20^{\circ}$ ), three (cultivated land, forest and grassland) and three classes (loamy sand, loam and clay), respectively. The other land cover types and soil types are not used in the computation of the hazard occurrence rates because we did not find any reported landslide or debris flow event under these types.

\section{Results}

\subsection{Spatiotemporal distributions of landslide and debris flow events}

The locations of the recorded landslide and debris flow events and the resultant casualties from 2009 to 2012 are shown in Fig. 2. It is clear that all of these recorded landslide and debris flow events are located to the south of $36^{\circ} \mathrm{N}$ (Fig. 2). In general, debris flow events are distributed further south than landslides. Most of the landslide and debris flow events are near the rivers and/or in the areas with steep slopes

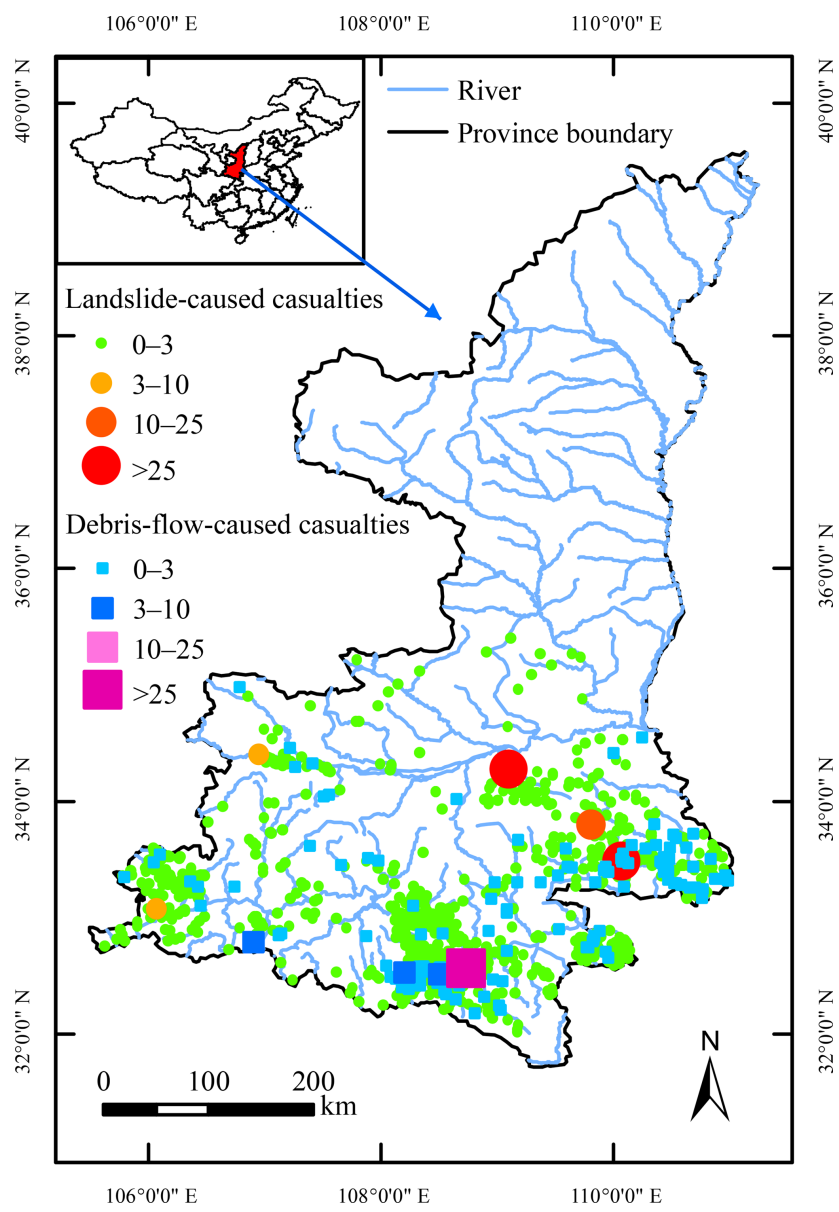

Figure 2. Locations of reported rainfall-triggered landslide and debris flow events and the resultant casualties in Shaanxi Province from 2009 to 2012; the inset shows the location of Shaanxi Province in China.

(see Figs. 2 and 1a). In addition, the landslide events outnumber the debris flow events (Fig. 2), indicating that landslide occurs more frequently than debris flow in this region.

There were a total of 1177 reported rainfall-triggered landslide events in Shaanxi Province from 2009 to 2012 with 69, 619, 332 and 157 events in the 4 years (Fig. 3a), while a total of 209 rainfall-triggered debris flow events occurred in this province during the same period, with $6,175,13$ and 15 events in the 4 years (Fig. 3a). More than half of the two types of events occurred in 2010. The corresponding casualties are clearly proportional to the number of hazards (Fig. 3a). In particular, landslides and debris flows in 2010 killed 72 and 73 people, respectively. During the 4-year period, the reported landslide and debris flow hazards caused the deaths of 131 and 78 people, respectively (Fig. 3a), indicating that the two types of hazards are destructive in this region. Generally, debris flow is even more destructive than landslide. Although the number of debris flow events accounts for only $15 \%$ of the total events of the two hazards, the debris-flow-caused fatalities are $37.32 \%$ of the total 


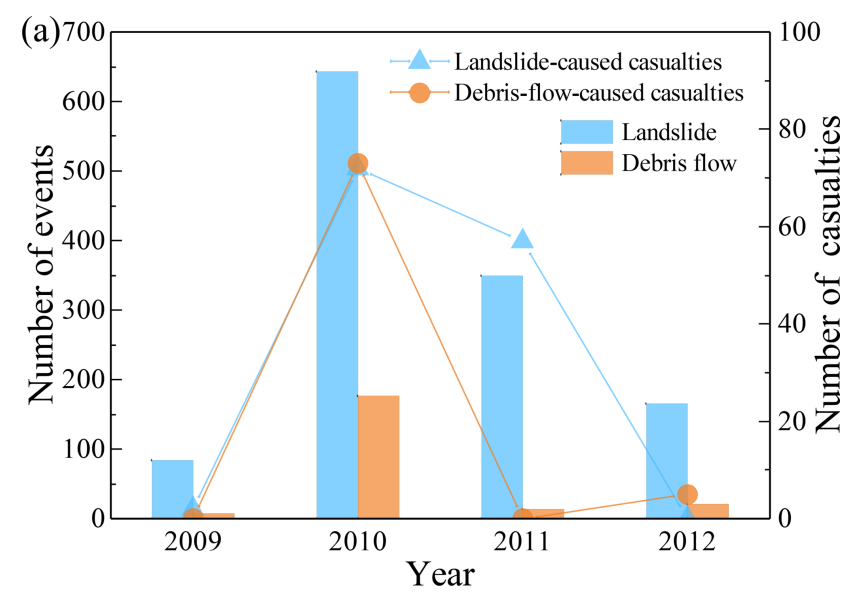

(b)

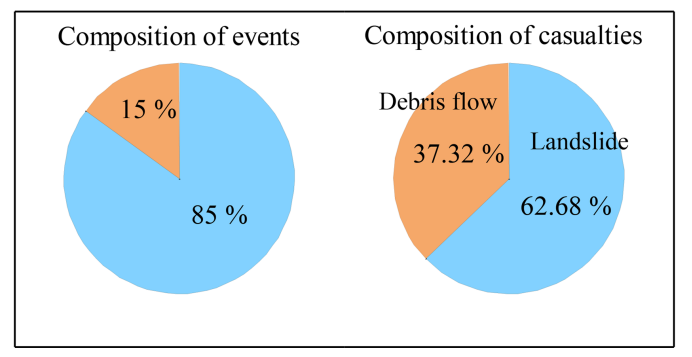

Figure 3. (a) Interannual distributions of reported landslide and debris flow events and the associated casualties from 2009 to 2012 and (b) pie charts of the disaster types and their corresponding casualties.

deaths caused by the two hazards (Fig. 3b). The above results suggest that debris flow imposes a higher threat to people in this province per event than landslide.

In terms of interannual distributions of the two hazards, total annual numbers of landslide and debris flow hazards show a correlation with annual rainfall amount (Fig. 4a). However, annual rainfall amount is not the only factor influencing the occurrences of the two hazards. For example, there is more annual rainfall in 2011 and 2012 than in 2010, but the total numbers of landslide and debris flow events in 2011 and 2012 are actually lower than these in 2010 (Fig. 4a). In terms of intra-annual distributions of the two hazards, landslide events are mainly distributed between July and September, which are the top 3 months in terms of both total rainfall amount (Fig. 4b) and average rainfall intensity (Fig. 4c). Meanwhile, almost all debris flow events occurred in July, the month having the largest rainfall amount (Fig. 4b) and rainfall intensity (Fig. 4c) with multi-year mean values of $117 \mathrm{~mm} \mathrm{month}^{-1}$ and $0.96 \mathrm{~mm} \mathrm{~h}^{-1}$, respectively, during a year. Statistical analysis shows that rainfall between July and September accounts for $63.6 \%$ of annual rainfall, while the proportions of landslide and debris flow events during the 3 months are $98.6 \%$ and $100 \%$ of annual events, respectively. As can be seen, the landslide and debris flow hazards are seasonal hazards in Shaanxi Province and mainly occur during the rainy season.
The above results show that the landslide season is longer than the debris flow season.

We further analyzed the latitudinal distribution of annual rainfall, the number of landslides, the number of debris flows, the zonal average slope and the percentages of dominant land cover by dividing the region into four latitude bins (31$33,33-34,34-35$ and $35-36^{\circ} \mathrm{N}$ ). As there are no reported landslide and debris flow events in the areas north to $36^{\circ} \mathrm{N}$, we excluded these regions for analyzing the distributions of these hazards and their relations to rainfall, terrain slope and land cover in these areas. There are apparent latitudinal gradients in annual rainfall and the numbers of reported landslide and debris flow events, which all decrease from the south to the north (Fig. 5). The regional average terrain slope generally decreases from the south to the north with values of 23.4, 23.7, 10.7 and $11.4^{\circ}$ in the four latitude bins (Fig. 5). These results suggest that more rainfall and steeper slopes in the south can explain the larger numbers of reported landslides and debris flows in the south than in the north. In addition, the southern part of this province $\left(31-34^{\circ} \mathrm{N}\right)$ is mainly covered by forests $(\geq 78 \%$ ), while the regions between 34 and $35^{\circ} \mathrm{N}$ and between 35 and $36^{\circ} \mathrm{N}$ are dominated by cultivated lands $(50 \%)$ and grasslands $(47.1 \%)$, respectively (Figs. 5 and 1a). Although the southern region has a denser and better preserved land cover than the middle and northern parts, the southern region still experiences more landslide and debris flow hazards. This suggests that the meteorological and geomorphological factors such as rainfall and terrain slope play more important roles in controlling the landslide and debris flow occurrence than land cover.

\subsection{Impacts of rainfall amount, intensity and duration on the landslide and debris flow occurrence}

To attribute the causes of the landslide and debris flow hazards, we further analyzed the relationships between rainfall characteristics (antecedent accumulated amount, duration and intensity) and the occurrence rates of the two hazards. Both the number of landslide events and the number of debris flow events are not the least in the smallest antecedent rainfall amount. However, the number of landslide and debris flow events increases with an increasing amount of antecedent rainfall in the other four classes (Fig. 6a). Meanwhile, the occurrence rate of debris flow exponentially increases with increasing antecedent rainfall amount $(R=$ $\left.0.0022 \exp \left(1.8127 P_{\mathrm{a}}\right) ; R^{2}=0.988\right)$ (Fig. 6a). A similar relationship appears between the landslide occurrence rate and antecedent rainfall amount $\left(R=0.0034 \exp \left(1.6681 P_{\mathrm{a}}\right)\right.$; $\left.R^{2}=0.977\right)$. However, the landslide occurrence rate is higher than the debris flow occurrence rate when antecedent accumulated rainfall is lower than $100 \mathrm{~mm}$ (Fig. 6a). Once antecedent accumulated rainfall is above $100 \mathrm{~mm}$, the debris flow occurrence rate becomes much larger than the landslide occurrence rate (Fig. 6a). This suggests that triggering a de- 


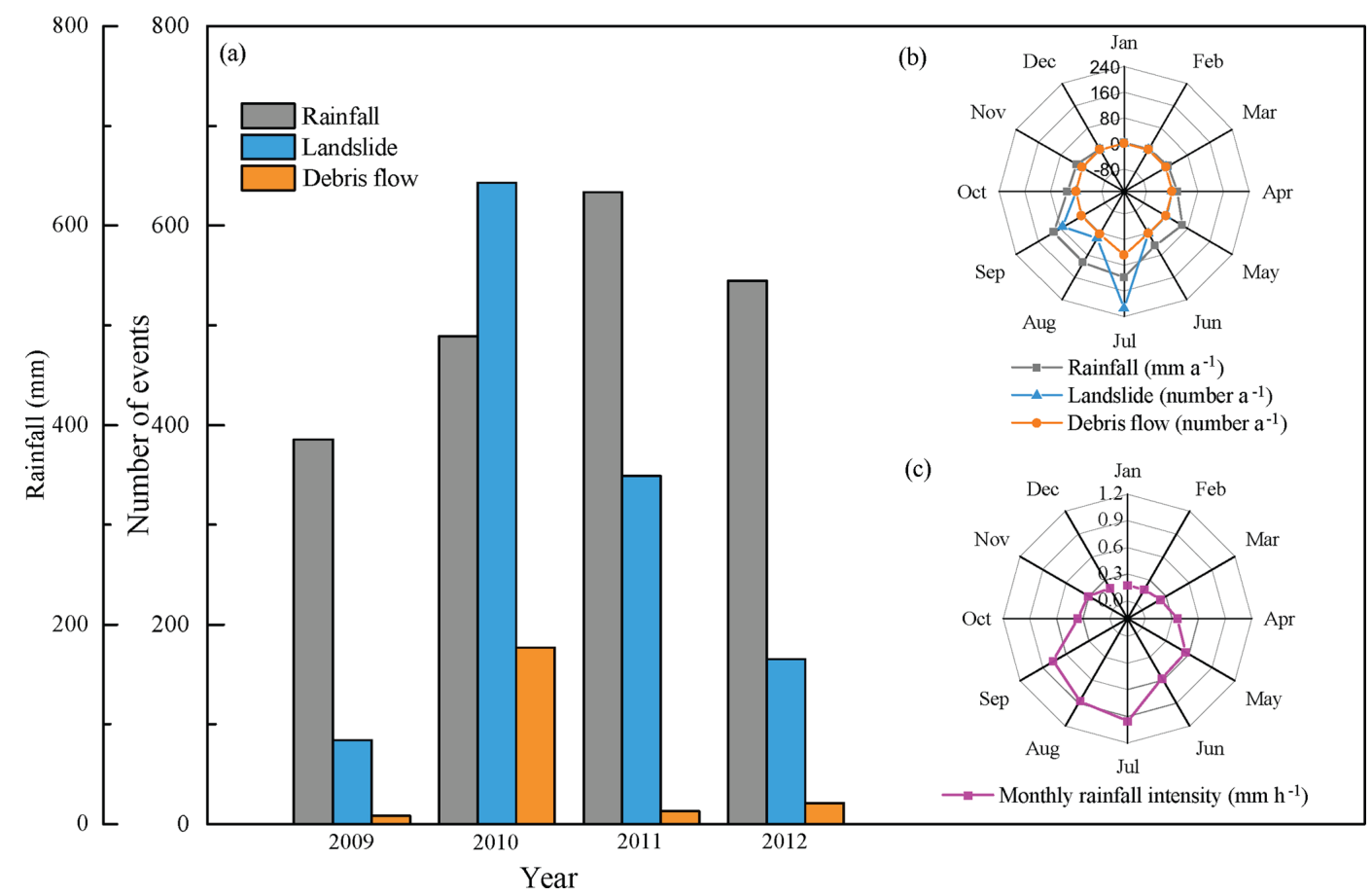

Figure 4. (a) Yearly distributions and (b) monthly distributions of rainfall amount, the number of landslide events, and the number of debris flow events from 2009 to 2012 and (c) the distribution of multi-year mean monthly rainfall intensity.

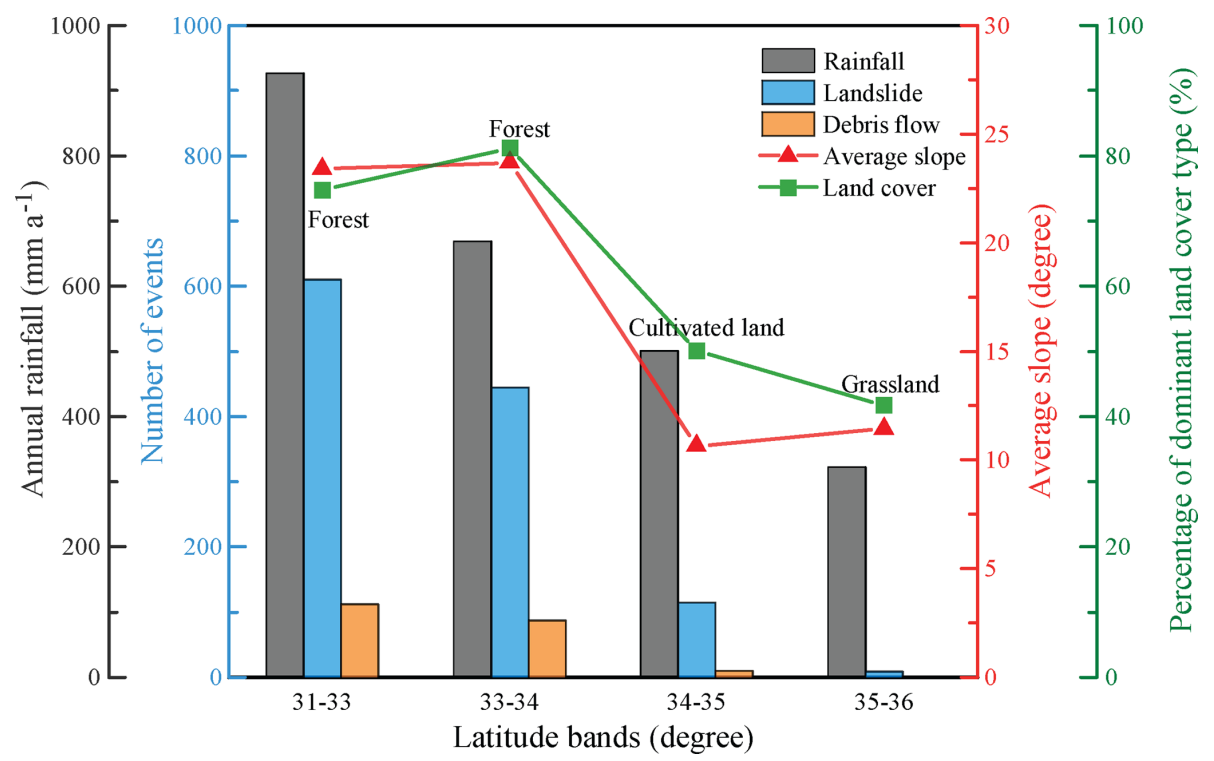

Figure 5. Distributions of annual rainfall amount, landslide events, and debris flow events along the latitude bands and spatial average slopes and percentages of dominant land cover types in these latitude bands.

bris flow generally requires more rainfall than triggering a landslide.

The occurrence rates of the two hazards also show positive exponential relationships with the rainfall duration $\left(R=0.0002 \exp (1.7175 D), R^{2}=0.997\right.$ for landslide; $R=0.00009 \exp (1.9526 D), R^{2}=0.977$ for debris flow)
(Fig. 6b). In addition, the occurrence rates of the two hazards also show positive exponential relationships with the average rainfall intensity (Fig. 6c). These results indicate that rainfall amount, duration and intensity all play an important role in controlling the landslide and debris flow occurrence in this region. In addition, the three rainfall metrics usually corre- 
(a)

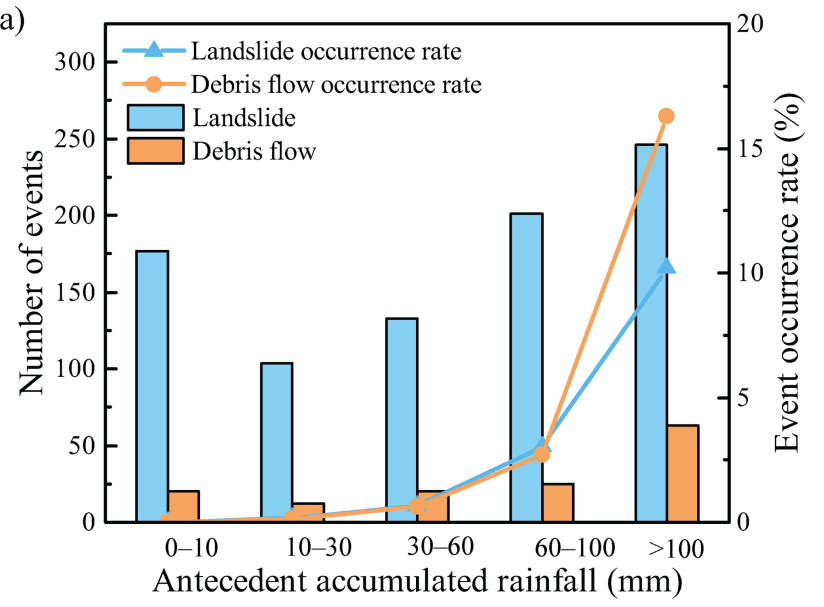

(b)

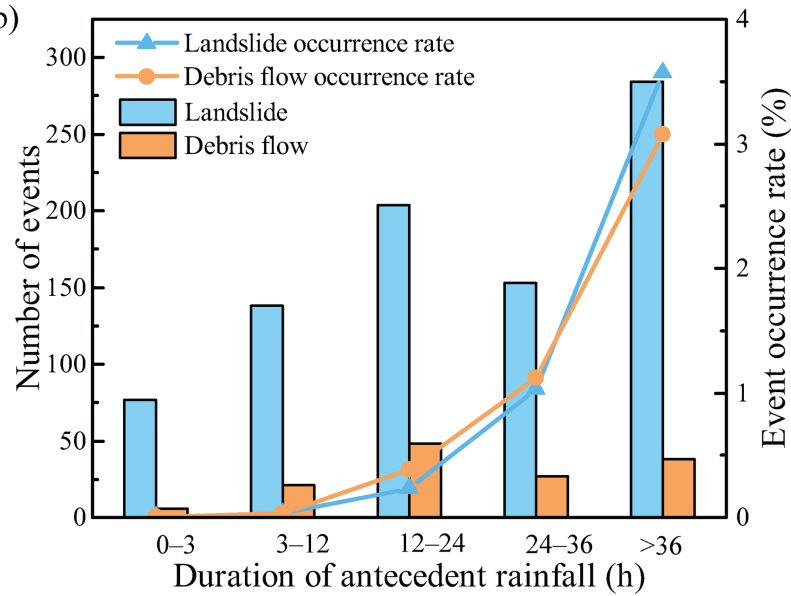

(c)

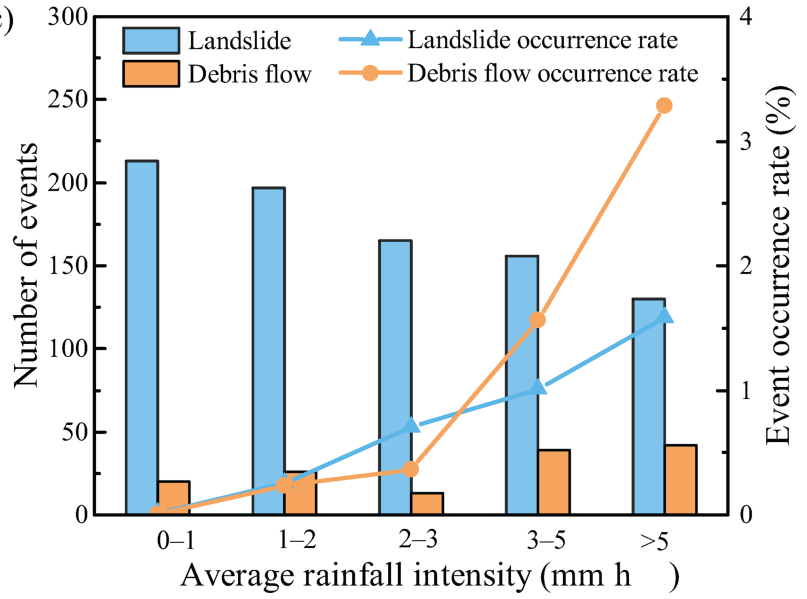

Figure 6. Relationship of occurrence rates of landslide and debris flow events with the corresponding (a) accumulated amount of antecedent continuous rainfall, (b) rainfall duration and (c) average rainfall intensity.

late with each other to some extent. In other words, the rainfall event that has the largest accumulated rainfall usually has a long duration and high average rainfall intensity.

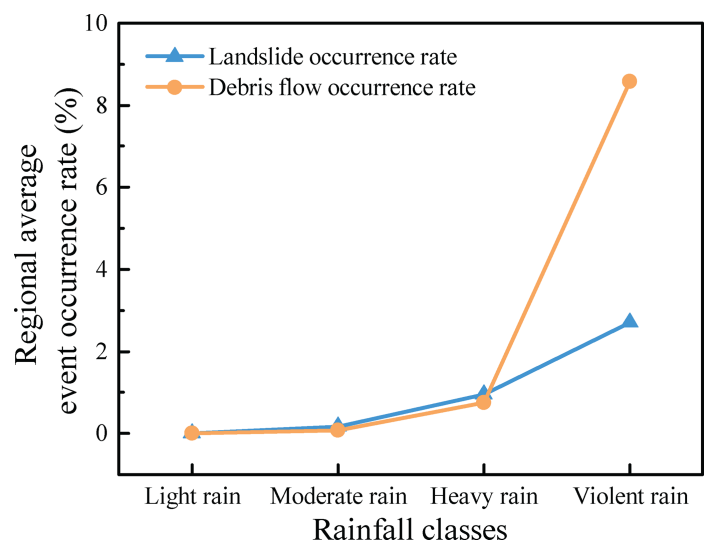

Figure 7. Regional average occurrence rates of landslide and debris flow events under different rainfall intensity classes.

In terms of the rainfall intensity, rainfall events can be classified into four classes, i.e., light rain, moderate rain, heavy rain and violent rain according to the American Meteorology Society. Therefore, we also calculated the regional average occurrence rates of landslide and debris flow under the four rain classes. Similar to the relationships between the occurrence rates and rainfall intensity (Fig. 6c), the regional average occurrence rates of the two hazards increase largely with increasing rainfall class (Fig. 7). Furthermore, Fig. 8 shows the spatial maps of landslide and debris occurrence rates under different rain classes. As rain becomes severe, both landslide and debris flow occur on more grid cells (Fig. 8a and h). For example, light rains caused 163 landslide events and 26 debris flow events during the 4-year period with average occurrence rates of $0.006 \%$ and $0.005 \%$, respectively. In contrast, violent rains have led to 273 landslide events and 60 debris flow events during the same period with average occurrence rates of $2.70 \%$ and $8.57 \%$, respectively. Meanwhile, the landslide occurrence rates on the grid cells that experience at least one landslide event during the 4-year period increase with increased rainfall intensity as well (Fig. 8a-d). As shown in Fig. 8e-h, the debris flow occurrence rates on the grid cells that experience at least one debris flow event during the 4-year period show a similar correlation with the rain classes (or rainfall intensity classes).

\subsection{Relationship of the landslide and debris flow occurrence with slope, land cover type and soil type}

Terrain, in particular terrain slope, is another important factor determining slope stability. Therefore, we grouped the $90 \mathrm{~m}$ grid cells with at least one reported landslide or debris flow event during the study period into five slope bins, i.e., $0-2,2$ $5,5-10,10-20$ and $>20^{\circ}$, and computed the respective landslide and debris flow occurrence rates. It is obvious that there are strong positive correlations between the occurrence rates of the two hazards and the slope angle (Fig. 9). Once again, the landslide occurrence rate is clearly larger than the debris 


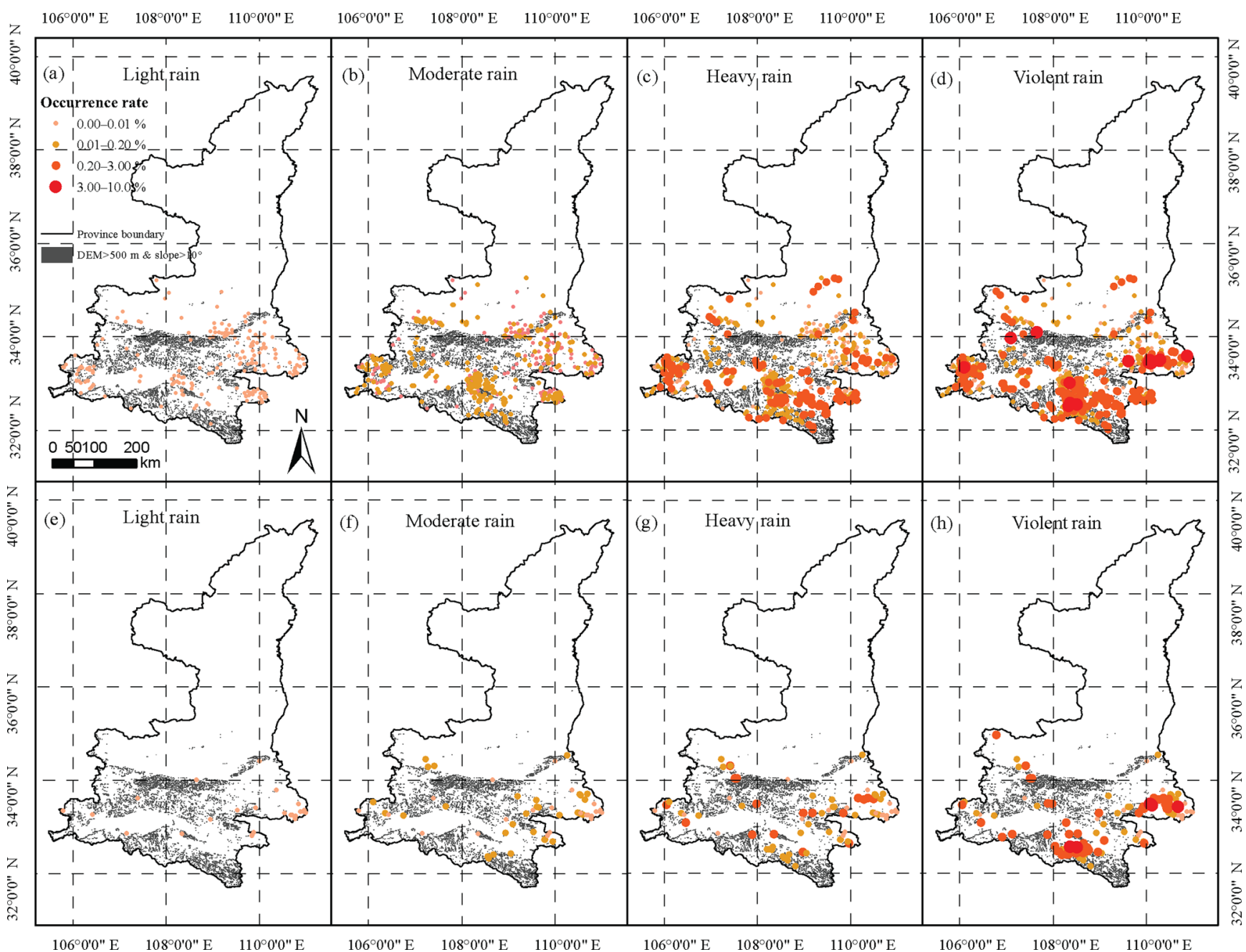

Figure 8. Spatial distributions of the occurrence rates of (a-d) landslide and (e-h) debris flow under four rainfall intensity classes: light rain, moderate rain, heavy rain and violent rain; only these grid cells with recorded landslide or debris flow events were analyzed and plotted in this figure.

flow occurrence rate under all five slope classes (Fig. 9). Relative to debris flow, landslide occurrence is more sensitive to terrain slope (Fig. 9). With increasing terrain slope, the landslide occurrence rate accelerates much faster than the debris flow occurrence rate.

We further analyzed the relationships of the hazard occurrence rates with land cover type and soil type. For debris flow, the occurrence rate is higher on the cultivated lands, followed by forests and grasslands (Fig. 10a). As shown in Fig. 1b, grasslands are mainly located in the north where there is less rainfall and much flatter terrain than in the south. Therefore, it is not a surprise to observe a lower debris flow occurrence rate on grasslands than on cultivated lands and forests. For landslide, the occurrence rate is also the highest on cultivated lands, but the occurrence rates on forests and grasslands are very similar (Fig. 10a). Higher occurrence rates for both landslide and debris flow on cultivated lands than on

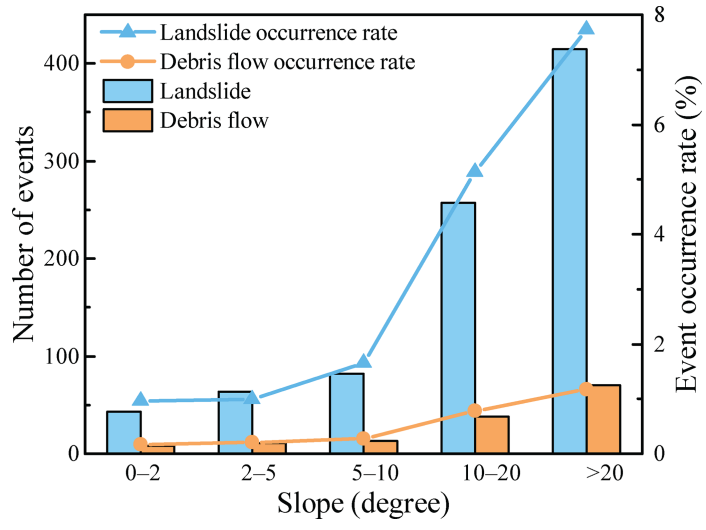

Figure 9. Occurrence rates of landslide and debris flow under different degrees of terrain slopes. 

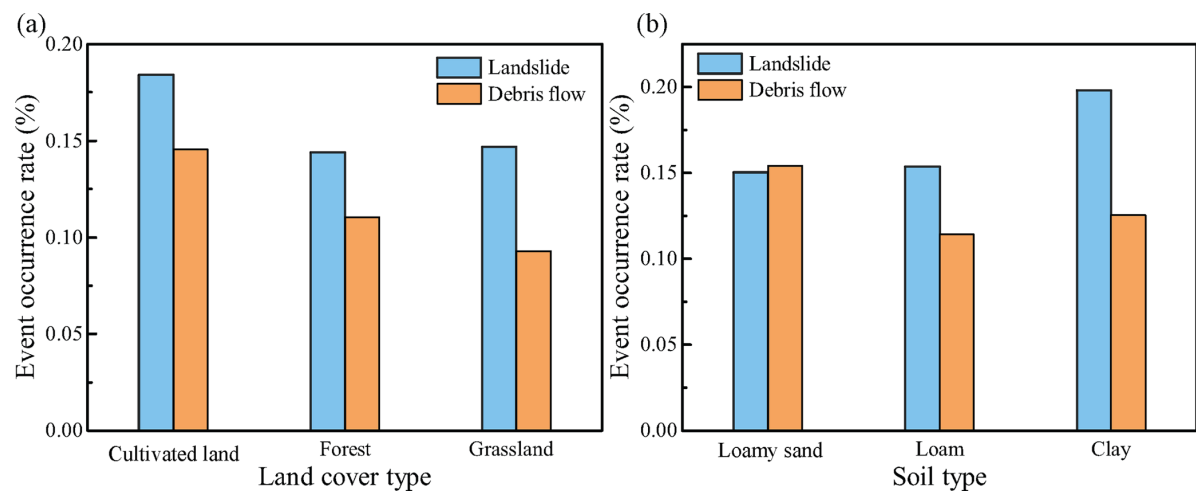

Figure 10. Occurrence rates of landslide and debris flow under different (a) land cover types and (b) soil types.

forests and grassland suggest that the destruction and conversion of natural dense land cover can weaken slope stability, making these areas more susceptible to landslides.

In this region, our analysis based on the available data does not show that soil type imposes apparent consistent effects on the occurrence rates of landslide and debris flow. For example, landslide has the highest occurrence rate in the clay soil among the tree-dominant soil types in this region, while the landslide occurrence rates in the loam soil and the loamy sand soil are comparable (Fig. 10b). In contrast, debris flow has the highest occurrence rate in the loamy sand soil, while the debris flow occurrence rates are similar in the loam and clay soils (Fig. 10b).

\section{Discussions}

Based on the survey of rainfall-induced landslide and debris flow hazards from 2009 to 2012 in Shaanxi Province, China, our results show that both landslide and debris flow occur frequently in this region and are mainly distributed in the southern part of this province, which has more rainfall and steeper terrain slopes than the other areas of this province. Landslide happens more frequently than debris flow. Although the number of the reported debris flow events is only onesixth of the number of the recorded landslide events in this region, the debris-flow-caused casualties are equal to $60 \%$ of the landslide-caused casualties. Clearly, debris flow is more destructive than landslide in this region in terms of the casualty per event. Like many areas in the world, debris flow usually occurs in areas near stream networks, which usually have a higher population. Moreover, debris flow usually carries more materials and travels a longer distance than landslide, making it more harmful to people and property (Ietto et al., 2016). In fact, most debris flow events are initialized from landslide and cause more damage to the environment and society (Peng et al., 2015; Zhou et al., 2013).

Our results show that rainfall characteristics including rainfall amount, rainfall intensity and rainfall duration all play important roles in controlling the occurrence of land- slide and debris flow. Relatively speaking, rainfall amount and rainfall duration have higher impacts on the occurrence of landslide and debris flow than average rainfall intensity in this region. This is because a rainstorm with higher average rainfall intensity does not necessary last for a long duration and leads to a larger accumulated rainfall amount. In addition, one has to note that the three rainfall characteristics do not necessarily correlate with each other. Previous studies have pointed out that different types of landslides and debris flows have different critical rainfall conditions for failure considering the different geologic and geomorphologic conditions (Zezere et al., 2015; Guzzetti et al., 2008). For example, rapid debris flows are typically triggered by very intense showers concentrated in a few hours, while shallow translational soil slips are usually triggered by intense precipitation falling within a few days (Zezere et al., 2015). In contrast, deep-seated landslides of rotational, translational and complex types are related to long periods (weeks to months) of nearly constant rainfall (Zezere et al., 2015; Chen et al., 2013). In general, rainfall with a long duration and large amount is more likely to trigger landslide and debris flow (Saito et al., 2014).

Terrain slope is another important factor influencing the slope stability since gravity makes these slopes with higher slope angles more vulnerable (Nourani et al., 2014; Dehnavi et al., 2015). In addition, terrains with steep slopes make plants harder to establish and grow. Furthermore, it is harder for vegetation roots to reach the sliding surface if the slope is steep (usually exceed $1.5 \mathrm{~m}$ ) (Ocakoglu et al., 2002; Cammeraat et al., 2005). In this case vegetation biomass may increase the weight of landslide body and promote the occurrence of landslides (Nilaweera and Nutalaya, 1999; Collison and Anderson, 1996). The terrain and vegetation can interact with each other to create complex hydrological and mechanical effects on the slope stability. Benefits from vegetation are conditional on the geological and geomorphological conditions (Nilaweera and Nutalaya, 1999; Collison and Anderson, 1996). 
Land cover type is another factor that impacts the slope stability. As shown in our results (Fig. 10), cultivated lands have higher landslide and debris flow occurrence rates than forests in the same climatic zone. Similar findings were also reported in previous research, showing that conversion of natural vegetated lands, in particular forests, to cultivated lands or the early-stage abandonment of cultivated lands can largely weaken slope stability by increasing surface water runoff, intensifying erosion processes and increasing soil instability (Begueria, 2006; Lopez-Saez et al., 2016; Persichillo et al., 2017). In addition, the slopes with woody vegetation are more stable than those with herbaceous vegetation because woody vegetation has deeper roots than herbaceous vegetation and can draw down soil moisture, making the slopes more stable (Kim et al., 2017; Begueria, 2006). In addition, some studies also show that the stand age, structure and composition of vegetation can influence the slope stability (Turner et al., 2010).

In this region, soil type does not appear to impose apparent consistent effects on the occurrence rates of landslide and debris flow based on the available data. These results suggest that soil type is not the dominant factor influencing the slope stability in this region. As shown in other studies, soil types and their physical properties such as cohesion, saturated hydraulic conductivity, porosity and friction angle have impacts on the slope failure and stability (Antinoro et al., 2017; van Asch and Malet, 2009; Zhang et al., 2016; Pasculli et al., 2017; Milne et al., 2012).

\section{Conclusions}

In this paper, we analyzed the spatiotemporal distributions, occurrence rates and resultant casualties of rainfall-triggered landslide and debris flow based on a survey from 2009 to 2012 in Shaanxi Province, China. Our results show that landslide has a higher occurrence rate and more extensive distribution than debris flow in Shaanxi Province, while both of the two hazards are concentrated in the south of this region with ample rainfall and relatively steep terrains. Debris flow is more destructive than landslide in terms of the casualties per event. Both landslide and debris flow show a clear seasonality corresponding to the rainy season in this region. Debris flow mainly occurs in July, whereas landslide usually takes place between July and September.

The characteristics of rainfall events including accumulated rainfall amount, duration, and intensity and terrain slope show the strongest impacts on the slope stability and the occurrence rates of landslide and debris flow. The landslide and debris flow occurrences have exponential relationships with all of the above four factors $(P<0.1)$. When accumulated rainfall amount and intensity are on the low and intermediate levels, landslide has a higher occurrence rate than debris flow. Conversely, the debris flow occurrence rate is much higher than the landslide occurrence rate when ac- cumulated rainfall amount and intensity are at a high level. Responses of the landslide and debris flow occurrence rates to rainfall duration do not differ much between each other. The occurrence of both landslide and debris flow also largely depends on the terrain slope, but landslide has a higher sensitivity to terrain slope than debris flow does. Our results also show that land cover also influences the occurrence of the two hazards to some extent in this region. In particular, both landslide and debris flow has lower occurrence rates on natural vegetated land than on cultivated lands. However, the study does not find an apparent relationship between the occurrence rates of the two hazards and soil type. In summary, we compiled an important data inventory of the rainfall-triggered landslide and debris flow hazards in Shaanxi Province, China, based on a 4-year survey and revealed the spatiotemporal distributions and characteristics of these events and the impacts of rainfall characteristics, topography and soil type on the occurrence of landslide and debris. This study not only provides an important inventory data for understanding the formation mechanisms and characteristics of the landslide and debris flow hazards but also adds valuable information for modeling and predicting the rainfall-triggered landslide and debris flow hazards to improve preparedness for and enhance resilience to these hazards in this region and the other similar areas.

Data availability. The DEM data used in this study were provided by the geospatial data cloud (http://www.gscloud.cn, DEM data, 2017). The land cover data were derived from GlobeLand302010 , which is a product of global land cover at a spatial resolution of $30 \mathrm{~m}$ derived from remote-sensing images in 2010 (Chen et al., 2015a, http://www.globeland30.cn, last access: 2 January 2017). The soil data are from the Harmonized World Soil Database (HWSD) v1.2 (https://daac.ornl.gov/SOILS/guides/ HWSD.html, Soil data, 2017). Rainfall data were provided by the National Meteorological Information Center of China Meteorological Administration (http://data.cma.cn, last access: 9 January 2019). The other data can be provided by the authors upon request.

Author contributions. KZ designed the study; SW and KZ conducted this study; KZ and SW wrote this paper; $\mathrm{HB}$ and $\mathrm{XZ}$ provided the data and reviewed this paper.

Competing interests. The authors declare that they have no conflict of interest.

Acknowledgements. This study was supported by the National Key Research and Development Program of China (2018YFC1508101 and 2016YFC0402701), National Natural Science Foundation of China (51879067, 41775111, 41875131), Natural Science Foundation of Jiangsu Province (BK20180022), Six Talent Peaks Project in Jiangsu Province (NY-004), Key Research \& Development Program of Ningxia Hui Automonous Region, China 
(2018BEG02010), Fundamental Research Funds for the Central Universities of China (2018B42914), Open Foundation of State Key Laboratory of Hydrology-Water Resources and Hydraulic Engineering (2017490311), and Priority Academic Program Development of Jiangsu Higher Education Institutions.

Edited by: Mario Parise

Reviewed by: two anonymous referees

\section{References}

Althuwaynee, O. F., Pradhan, B., Park, H. J., and Lee, J. H.: A novel ensemble bivariate statistical evidential belief function with knowledge-based analytical hierarchy process and multivariate statistical logistic regression for landslide susceptibility mapping, Catena, 114, 21-36, https://doi.org/10.1016/j.catena.2013.10.011, 2014.

Alvioli, M. and Baum, R. L.: Parallelization of the TRIGRS model for rainfall-induced landslides using the message passing interface, Environ. Model. Softw., 81, 122-135, 2016.

Antinoro, C., Arnone, E., and Noto, L. V.: The use of soil water retention curve models in analyzing slope stability in differently structured soils, Catena, 150, 133-145, 10.1016/j.catena.2016.11.019, 2017.

Baum, R. L., Godt, J. W., and Savage, W. Z.: Estimating the timing and location of shallow rainfall-induced landslides using a model for transient, unsaturated infiltration, J. Geophys. Res., 115, F03013, https://doi.org/10.1029/2009jf001321, 2010.

Begueria, S.: Changes in land cover and shallow landslide activity: A case study in the Spanish Pyrenees, Geomorphology, 74, 196206, https://doi.org/10.1016/j.geomorph.2005.07.018, 2006.

Blothe, J. H., Korup, O., and Schwanghart, W.: Large landslides lie low: Excess topography in the Himalaya-Karakoram ranges, Geology, 43, 523-526, https://doi.org/10.1130/g36527.1, 2015.

Bogaard, T. and Greco, R.: Invited perspectives: Hydrological perspectives on precipitation intensity-duration thresholds for landslide initiation: proposing hydro-meteorological thresholds, Nat. Hazards Earth Syst. Sci., 18, 31-39, https://doi.org/10.5194/nhess-18-31-2018, 2018.

Borga, M., Stoffel, M., Marchi, L., Marra, F., and Jakob, M.: Hydrogeomorphic response to extreme rainfall in headwater systems: Flash floods and debris flows, J. Hydrol., 518, 194-205, https://doi.org/10.1016/j.jhydrol.2014.05.022, 2014.

Cammeraat, E., van Beek, R., and Kooijman, A.: Vegetation succession and its consequences for slope stability in SE Spain, Plant Soil, 278, 135-147, https://doi.org/10.1007/s11104-005-5893-1, 2005.

Chen, J., Chen, J., Liao, A. P., Cao, X., Chen, L. J., Chen, X. H., He, C. Y., Han, G., Peng, S., Lu, M., Zhang, W. W., Tong, X. H., and Mills, J.: Global land cover mapping at $30 \mathrm{~m}$ resolution: A POK-based operational approach, ISPRS J. Photogram. Remote Sens., 103, 7-27, 2015a.

Chen, J. J., Zeng, Z. G., Jiang, P., and Tang, H. M.: Deformation prediction of landslide based on functional network, Neurocomputing, 149, 151-157, https://doi.org/10.1016/j.neucom.2013.10.044, 2015 b.

Chen, W., Chai, H. C., Zhao, Z., Wang, Q. Q., and Hong, H. Y.: Landslide susceptibility mapping based on GIS and support vec- tor machine models for the Qianyang County, China, Environ. Earth Sci., 75, 474, https://doi.org/10.1007/s12665-015-5093-0, 2016.

Chen, W., Pourghasemi, H. R., and Zhao, Z.: A GISbased comparative study of Dempster-Shafer, logistic regression and artificial neural network models for landslide susceptibility mapping, Geocarto Int., 32, 367-385, https://doi.org/10.1080/10106049.2016.1140824, 2017.

Chen, Y. C., Chang, K. T., Chiu, Y. J., Lau, S. M., and Lee, H. Y.: Quantifying rainfall controls on catchment-scale landslide erosion in Taiwan, Earth Surf. Proc. Land., 38, 372-382, 2013.

Collison, A. J. C. and Anderson, M. G.: Using a combined slope hydrology stability model to identify suitable conditions for landslide prevention by vegetation in the humid tropics, Earth Surf. Proc. Land., 21, 737-747, https://doi.org/10.1002/(Sici)10969837(199608)21:8<737::Aid-Esp674>3.0.Co;2-F, 1996.

Dehnavi, A., Aghdam, I. N., Pradhan, B., and Varzandeh, M. H. M.: A new hybrid model using step-wise weight assessment ratio analysis (SWAM) technique and adaptive neuro-fuzzy inference system (ANFIS) for regional landslide hazard assessment in Iran, Catena, 135, 122-148, https://doi.org/10.1016/j.catena.2015.07.020, 2015.

DEM data: Geospatial Data Cloud, available at: http://www. gscloud.cn, last access: 4 January 2017.

Gariano, S. L., Brunetti, M. T., Iovine, G., Melillo, M., Peruccacci, S., Terranova, O., Vennari, C., and Guzzetti, F.: Calibration and validation of rainfall thresholds for shallow landslide forecasting in Sicily, southern Italy, Geomorphology, 228, 653-665, 2015.

Glickman, T. S. and Walter, Z.: Glossary of Meteorology, 2nd Edn., Boston, MA, 2000.

Guzzetti, F., Peruccacci, S., Rossi, M., and Stark, C. P.: Rainfall thresholds for the initiation of landslides in central and southern Europe, Meteorol. Atmos. Phys., 98, 239-267, https://doi.org/10.1007/s00703-007-0262-7, 2007.

Guzzetti, F., Peruccacci, S., Rossi, M., and Stark, C. P.: The rainfall intensity-duration control of shallow landslides and debris flows: an update, Landslides, 5, 3-17, https://doi.org/10.1007/s10346007-0112-1, 2008.

Han, Z., Li, Y. G., Huang, J. L., Chen, G. Q., Xu, L. R., Tang, C., Zhang, H., and Shang, Y. H.: Numerical simulation for runout extent of debris flows using an improved cellular automaton model, B. Eng. Geol. Environ., 76, 961-974, 2017.

He, X. G., Hong, Y., Vergara, H., Zhang, K., Kirstetter, P. E., Gourley, J. J., Zhang, Y., Qiao, G., and Liu, C.: Development of a coupled hydrological-geotechnical framework for rainfall-induced landslides prediction, J. Hydrol., 543, 395-405, 2016.

Hong, H. Y., Pradhan, B., Xu, C., and Tien Bui, D.: Spatial prediction of landslide hazard at the Yihuang area (China) using two-class kernel logistic regression, alternating decision tree and support vector machines, Catena, 133, 266-281, https://doi.org/10.1016/j.catena.2015.05.019, 2015.

Hong, H. Y., Chen, W., Xu, C., Youssef, A. M., Pradhan, B., and Bui, D. T.: Rainfall-induced landslide susceptibility assessment at the Chongren area (China) using frequency ratio, certainty factor, and index of entropy, Geocarto Int., 32, 139-154, https://doi.org/10.1080/10106049.2015.1130086, 2017a.

Hong, H. Y., Liu, J. Z., Zhu, A. X., Shahabi, H., Pham, B. T., Chen, W., Pradhan, B., and Bui, D. T.: A novel hybrid integration model using support vector machines and random 
subspace for weather-triggered landslide susceptibility assessment in the Wuning area (China), Environ. Earth Sci., 76, 652, https://doi.org/10.1007/s12665-017-6981-2, 2017b.

Hong, Y., Adler, R., and Huffman, G.: Use of satellite remote sensing data in the mapping of global landslide susceptibility, Nat Hazards, 43, 245-256, 2007.

Hong, Y., He, X. G., Cerato, A., Zhang, K., Hong, Z., and Liao, Z. H.: Predictability of a Physically Based Model for Rainfallinduced Shallow Landslides: Model Development and Case Studies, Modern Technol. Landslide Monitor. Predict., 2, 165178, https://doi.org/10.1007/978-3-662-45931-7_9, 2015.

Huang, X. H., Li, Z. Y., Yu, D., Xu, Q., Fan, J. Y., Hao, Z., and Niu, Y. P.: Evolution of a giant debris flow in the transitional mountainous region between the Tibetan Plateau and the Qinling Mountain range, Western China: Constraints from broadband seismic records, J. Asian Earth Sci., 148, 181-191, https://doi.org/10.1016/j.jseaes.2017.08.031, 2017.

Ietto, F., Perri, F., and Cella, F.: Geotechnical and landslide aspects in weathered granitoid rock masses (Serre Massif, southern Calabria, Italy), Catena, 145, 301-315, https://doi.org/10.1016/j.catena.2016.06.027, 2016.

Jaboyedoff, M., Oppikofer, T., Abellan, A., Derron, M. H., Loye, A., Metzger, R., and Pedrazzini, A.: Use of LIDAR in landslide investigations: a review, Nat. Hazards, 61, 5-28, https://doi.org/10.1007/s11069-010-9634-2, 2012.

Jiang, R. G., Xie, J. C., He, H. L., Luo, J. G., and Zhu, J. W.: Use of four drought indices for evaluating drought characteristics under climate change in Shaanxi, China: 1951-2012, Nat. Hazards, 75, 2885-2903, https://doi.org/10.1007/s11069-014-1468-x, 2015.

Kim, J. H., Fourcaud, T., Jourdan, C., Maeght, J. L., Mao, Z., Metayer, J., Meylan, L., Pierret, A., Rapidel, B., Roupsard, O., de Rouw, A., Sanchez, M. V., Wang, Y., and Stokes, A.: Vegetation as a driver of temporal variations in slope stability: The impact of hydrological processes, Geophys. Res. Lett., 44, 4897-4907, https://doi.org/10.1002/2017gl073174, 2017.

Liao, Z. H., Hong, Y., Kirschbaum, D., and Liu, C.: Assessment of shallow landslides from Hurricane Mitch in central America using a physically based model, Environ. Earth Sci., 66, 16971705, https://doi.org/10.1007/s12665-011-0997-9, 2012.

Lopez-Saez, J., Corona, C., Eckert, N., Stoffel, M., Bourrier, F., and Berger, F.: Impacts of land-use and landcover changes on rockfall propagation: Insights from the Grenoble conurbation, Sci. Total Environ., 547, 345-355, https://doi.org/10.1016/j.scitotenv.2015.12.148, 2016.

Milne, F. D., BrownA, M. J., Knappett, J. A., and Davies, M. C. R.: Centrifuge modelling of hillslope debris flow initiation, Catena, 92, 162-171, 2012.

Montgomery, D. R. and Dietrich, W. E.: A physically based model for the topographic control on shallow landsliding, Water Resour. Res., 30, 1153-1171, 1994.

Montrasio, L. and Valentino, R.: A model for triggering mechanisms of shallow landslides, Nat. Hazards Earth Syst. Sci., 8, 1149-1159, https://doi.org/10.5194/nhess-8-1149-2008, 2008.

Naef, D., Rickenmann, D., Rutschmann, P., and McArdell, B. W.: Comparison of flow resistance relations for debris flows using a one-dimensional finite element simulation model, Nat. Hazards Earth Syst. Sci., 6, 155-165, https://doi.org/10.5194/nhess6-155-2006, 2006.
Nicolussi, K., Spotl, C., Thurner, A., and Reimer, P. J.: Precise radiocarbon dating of the giant Weis landslide (Eastern Alps, Austria), Geomorphology, 243, 87-91, https://doi.org/10.1016/j.geomorph.2016.05.001, 2015.

Nilaweera, N. S. and Nutalaya, P.: Role of tree roots in slope stabilisation, B. Eng. Geol. Environ., 57, 337-342, 1999.

Nourani, V., Pradhan, B., Ghaffari, H., and Sharifi, S. S.: Landslide susceptibility mapping at Zonouz Plain, Iran using genetic programming and comparison with frequency ratio, logistic regression, and artificial neural network models, Nat. Hazards, 71, 523-547, https://doi.org/10.1007/s11069-013-0932-3, 2014.

Ocakoglu, F., Gokceoglu, C., and Ercanoglu, M.: Dynamics of a complex mass movement triggered by heavy rainfall: a case study from NW Turkey, Geomorphology, 42, 329-341, https://doi.org/10.1016/S0169-555x(01)00094-0, 2002.

Pasculli, A., Sciarra, N., Esposito, L., and Esposito, A. W.: Effects of wetting and drying cycles on mechanical properties of pyroclastic soils, Catena, 156, 113-123, https://doi.org/10.1016/j.catena.2017.04.004, 2017.

Peng, J. B., Fan, Z. J., Wu, D., Zhuang, J. Q., Dai, F. C., Chen, W. W., and Zhao, C.: Heavy rainfall triggered loess-mudstone landslide and subsequent debris flow in Tianshui, China, Eng. Geol., 186, 79-90, 2015.

Persichillo, M. G., Bordoni, M., and Meisina, C.: The role of land use changes in the distribution of shallow landslides, Sci. Total Environ., 574, 924-937, https://doi.org/10.1016/j.scitotenv.2016.09.125, 2017.

Peruccacci, S., Brunetti, M. T., Luciani, S., Vennari, C., and Guzzetti, F.: Lithological and seasonal control on rainfall thresholds for the possible initiation of landslides in central Italy, Geomorphology, 139, 79-90, https://doi.org/10.1016/j.geomorph.2011.10.005, 2012.

Petley, D. N.: On the impact of climate change and population growth on the occurrence of fatal landslides in South, East and SEAsia, Q. J. Eng. Geol. Hydrogeol., 43, 487-496, https://doi.org/10.1144/1470-9236/09-001, 2010.

Pradhan, B. and Youssef, A. M.: Manifestation of remote sensing data and GIS on landslide hazard analysis using spatial-based statistical models, Arab. J. Geosci., 3, 319-326, https://doi.org/10.1007/s12517-009-0089-2, 2010.

Qin, S. Q., Jiao, J. J., and Wang, S. J.: The predictable time scale of landslides, B. Eng. Geol. Environ., 59, 307-312, 2001.

Saito, H., Korup, O., Uchida, T., Hayashi, S., and Oguchi, T.: Rainfall conditions, typhoon frequency, and contemporary landslide erosion in Japan, Geology, 42, 999-1002, 2014.

Soil data: Regridded Harmonized World Soil Database v1.2, available at: https://daac.ornl.gov/SOILS/guides/HWSD.html, last access: 22 Feburary 2017.

Sorbino, G., Sica, C., and Cascini, L.: Susceptibility analysis of shallow landslides source areas using physically based models, Nat. Hazards, 53, 313-332, https://doi.org/10.1007/s11069-0099431-y, 2010.

Sun, P., Peng, J. B., Chen, L. W., Lu, Q. Z., and Igwe, O.: An experimental study of the mechanical characteristics of fractured loess in western China, B. Eng. Geol. Environ., 75, 1639-1647, https://doi.org/10.1007/s10064-015-0793-y, 2016.

Turner, T. R., Duke, S. D., Fransen, B. R., Reiter, M. L., Kroll, A. J., Ward, J. W., Bach, J. L., Justice, T. E., and Bilby, R. E.: Landslide densities associated with rainfall, stand age, and topography 
on forested landscapes, southwestern Washington, USA, Forest Ecol. Manage., 259, 2233-2247, 2010.

van Asch, T. W. J. and Malet, J. P.: Flow-type failures in fine-grained soils: an important aspect in landslide hazard analysis, Nat. Hazards Earth Syst. Sci., 9, 1703-1711, https://doi.org/10.5194/nhess-9-1703-2009, 2009.

Wooten, R. M., Gillon, K. A., Witt, A. C., Latham, R. S., Douglas, T. J., Bauer, J. B., Fuemmeler, S. J., and Lee, L. G.: Geologic, geomorphic, and meteorological aspects of debris flows triggered by Hurricanes Frances and Ivan during September 2004 in the Southern Appalachian Mountains of Macon County, North Carolina (southeastern USA), Landslides, 5, 31-44, 2008.

$\mathrm{Wu}, \mathrm{H}$. and Qian, H.: Innovative trend analysis of annual and seasonal rainfall and extreme values in Shaanxi, China, since the 1950s, Int. J. Climatol., 37, 2582-2592, https://doi.org/10.1002/joc.4866, 2017.

Zezere, J. L., Vaz, T., Pereira, S., Oliveira, S. C., Marques, R., and Garcia, R. A. C.: Rainfall thresholds for landslide activity in Portugal: a state of the art, Environ. Earth Sci., 73, 2917-2936, 2015.

Zhang, K., Xue, X., Hong, Y., Gourley, J. J., Lu, N., Wan, Z., Hong, Z., and Wooten, R.: iCRESTRIGRS: a coupled modeling system for cascading flood-landslide disaster forecasting, Hydrol. Earth Syst. Sci., 20, 5035-5048, https://doi.org/10.5194/hess-20-50352016, 2016.
Zhang, P., Ma, J. Z., Shu, H. P., Han, T., and Zhang, Y. L.: Simulating debris flow deposition using a two-dimensional finite model and Soil Conservation Service-curve number approach for Hanlin gully of southern Gansu (China), Environ. Earth Sci., 73, 6417-6426, 2015.

Zhang, Y. C., Zhang, F., Zhang, J. Q., Guo, E. L., Liu, X. P., and Tong, Z. J.: Research on the Geological Disaster Forecast and Early Warning Model Based on the Optimal Combination Weighing Law and Extension Method: a Case Study in China, Pol. J. Environ. Stud., 26, 2385-2395, https://doi.org/10.15244/pjoes/69100, 2017.

Zhou, J. W., Cui, P., Yang, X. G., Su, Z. M., and Guo, X. J.: Debris flows introduced in landslide deposits under rainfall conditions: The case of Wenjiagou gully, J. Mt. Sci.-Engl., 10, 249260, 2013.

Zhu, X., Xu, Q., Tang, M. G., Nie, W., Ma, S. Q., and Xu, Z. P.: Comparison of two optimized machine learning models for predicting displacement of rainfall-induced landslide: A case study in Sichuan Province, China, Eng. Geol., 218, 213-222, https://doi.org/10.1016/j.enggeo.2017.01.022, 2017.

Zhuang, J. Q. and Peng, J. B.: A coupled slope cutting-a prolonged rainfall-induced loess landslide: a 17 October 2011 case study, B. Eng. Geol. Environ., 73, 997-1011, 2014. 